DOI $10.15421 / 4221006$

УДК 539.3

О. А. Дисковський, д-р техн. наук, Ю. П. Синиціна, канд. техн. наук, О. Д. Станіна, канд. техн. наук

\title{
ОПТИМАЛЬНЕ ПРОЄКТУВАННЯ ГОФРОВАНИХ КІЛЕЦЬ ЯК ЕЛЕМЕНТІВ СУДИННИХ СТЕНТІВ
}

Розглянуто деформацію кільця, гофрованого перпендикулярно радіусу, що знаходиться під дією зовнішнього тиску. Застосовано метод асимптотичної гомогенізації. Отримано асимптотичну формулу залежності величини деформації від величини зовнішнього тиску для довільного гладкого профілю гофри. Поставлено задачу оптимізації форми профілю гофри по відношенню до супротиву зовнішнього тиску. Знайдений оптимальний профіль по своїй ефективності виявився близьким до синусоїдального, зменшення деформації склало менше одного відсотка.

Ключові слова: судинний стент; гофроване кільце; зовнішній тиск; метод асимптотичної гомогенізації; залежність деформації від зовнішнього тиску; оптимізація форми профрілю гофри.

Вступ. Останнім часом знаходять застосування гофровані кільця (рис. 1) як складові елементи судинних стентів (рис. 2). Ці структури зазвичай моделюються із застосуванням аналізу скінченних елементів, але існує також потреба в більш спрощених підходах оцінки можливих варіантів проєктування.

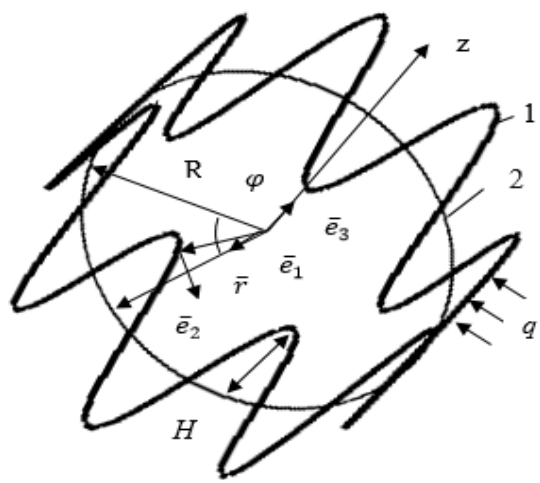

Рис. 1 - Гофроване кільце:

1; 2 - базове кільце рівновіддалене від вершин гофри; Н - амплітуда гофри;

$q$ - нормальна до циліндричної поверхні радіуса $R$ розподілене навантаження, що діє з боку стінок судини

() О. А. Дисковський, Ю. П. Синиціна, О. Д. Станіна, 2021 


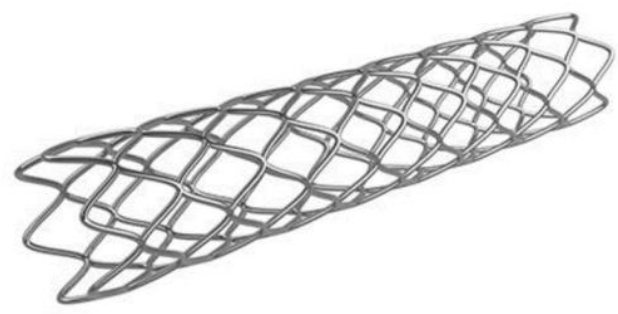

Рис. 2 - Приклад судинного стенту [DAIS NEWS. June 12. 2017. Open Access]

Метою роботи є проєктування форми гофрування, яка забезпечує найбільшу кільцеву жорсткість гофрованого кільця при заданому периметрі. Для цього будується гомогенна модель гофрованого кільця за допомогою метода асимптотичної гомогенізації [1 - 3].

Геометричні співвідношення. Векторне рівняння осьової лінії в циліндричній системі координат (рис. 2)

$$
\bar{r}=\operatorname{Re}_{1}+Z(n \phi) \bar{e}_{3},
$$

де $Z=H \theta(n \varphi), H$ - амплітуда гофри; $\theta(n \varphi)$ - періодична ффункція 3 періодом $2 \pi / n ; n$ - кількість хвиль гофри. Функція $\theta(n \varphi)$, яка визначає форму гофри, симетрична щодо базової окружності 2 (рис. 2), $-1 \leq \theta(n \varphi) \leq 1,0 \leq \varphi \leq 2 \pi$.

Одиничні вектори головної нормалі $\bar{e}_{1}^{\prime}$, дотичної $\bar{e}_{2}^{\prime}$, бінормалі $\overline{e^{\prime}}{ }_{3}$ осьової лінії

$$
\begin{gathered}
\bar{e}_{1}^{\prime}=\frac{\left[\bar{r}_{\phi} \times \bar{r}_{\phi \phi}\right] \times \bar{r}_{\phi}}{\left|\left[\bar{r}_{\phi} \times \bar{r}_{\phi \phi}\right] \times \bar{r}_{\phi}\right|}=\frac{1}{A B}\left(A^{2} \bar{e}_{1}+\beta \beta_{\phi} \bar{e}_{2}-\beta_{\phi} \bar{e}_{3}\right) \\
\bar{e}_{2}^{\prime}=\frac{\bar{r}_{\phi}}{\left|\bar{r}_{\phi}\right|}=\frac{1}{A}\left(\bar{e}_{2}+\beta_{\phi} \bar{e}_{3}\right) \\
\bar{e}_{3}^{\prime}=\frac{\left[\bar{r}_{\phi} \times \bar{r}_{\phi \phi}\right]}{\left.\mid \bar{r}_{\phi} \times \bar{r}_{\phi \phi}\right] \mid}=\frac{1}{B}\left(\beta_{\phi} \bar{e}_{1}-\beta \bar{e}_{2}+\bar{e}_{3}\right)
\end{gathered}
$$

де $(\cdot)_{\varphi}=\frac{d}{d_{\varphi}} ; A=\sqrt{1+\beta^{2}} ; \beta=z_{\varphi} ; z=\frac{z}{R} ; B=\sqrt{1+\beta^{2}+\beta_{\varphi}^{2}}$. 
Рівняння рівноваги. Розглянемо елемент гофри довжиною $d s$ і діючі на нього сили, отримуємо два векторних рівняння рівноваги

$$
\left\{\begin{array}{c}
\overline{F_{\varphi}}+R A \bar{q}=0 \\
\overline{M_{\varphi}}+R A \overline{e_{2}^{\prime}} \times \bar{F}=0 .
\end{array}\right.
$$

Векторні рівняння (5) інваріантні по відношенню до будь-якій системі координат. Запишемо ці рівняння щодо координат, пов'язаних з базовою круговою окружністю (рис. 2). Для цього представимо вектори, що входять в рівняння (5), у вигляді розкладів по базису $\overline{e_{i}}(i=1-3)$ :

$$
\begin{gathered}
\bar{F}=F_{1} \overline{e_{1}}+F_{2} \overline{e_{2}}+F_{3} \overline{e_{3}} ; \\
\bar{M}=M_{1} \overline{e_{1}}+M_{2} \overline{e_{2}}+M_{3} \overline{e_{3}} ; \\
\bar{q}=q \overline{e_{1}},
\end{gathered}
$$

де $q=$ const .

Підставляючи розкладання (6) в (5), після перетворень одержуємо рівняння рівноваги в проєкціях на осі базової окружності

$$
\begin{gathered}
F_{2 \varphi \varphi}-F_{2}=-R A q ; \\
M_{3 \varphi \varphi \varphi}+M_{3 \varphi}=R^{2} A_{\varphi} q .
\end{gathered}
$$

Гомогенізація рівнянь рівноваги. Рівняння рівноваги (7), (8) дозволяють визначити напружений стан гофрованого кільця при заданій формі гофри (1). Для задачі оптимізації цієї фрорми необхідно знайти розв'язок в загальному вигляді, для невизначеної форми. Такий розв'язок можна отримати за допомогою методу асимптотичної гомогенізації.

Проєкції внутрішніх зусиль та моменту (6) представимо у вигляді

$$
F_{i}=\sum_{k=0}^{\infty} n^{-k} F_{i k}(\varphi, \xi) ; M_{i}=\sum_{k=0}^{\infty} n^{-k} M_{i k}(\varphi, \xi),
$$

де $\xi=n \varphi, F_{i k}, M_{i k}$ - періодичні по $\xi$ функції с періодом $2 \pi$.

Підставляючи розкладання (9) у рівняння (7), (8), після розбиття по степенях $n$ та застосування оператора усереднення $\int_{0}^{2 \pi}(\ldots) d \xi$, отримуємо 


$$
F_{20}=R_{a q} ; F_{10}=0 ; M_{10}=M_{20}=M_{30}=0 .
$$

Неважко знайти наступні наближення асимптотичних розкладів (9), наприклад

$$
M_{11}=R^{2} z a q+C(\varphi)
$$

де $C(\varphi) \equiv 0$ знаходиться з умови $\int_{0}^{2 \pi} M_{11} d \xi=0$.

Для завдання оптимізації профрілю гофри обмежимося нульовим наближенням напруженого стану, яке збігається з напруженим станом гладкого кругового кільця під дією рівномірного, в даному випадку усередненого, зовнішнього тиску.

Рівняння деформації. Для встановлення залежності $u_{1}=u_{1}(q)$ розглянемо стиснення плоского гофрованого стрижня силами $F_{20}$ (рис. 3) і прирівняємо його деформацію до деформації гофрованого кільця $\varepsilon=\frac{u_{1}}{R}$.

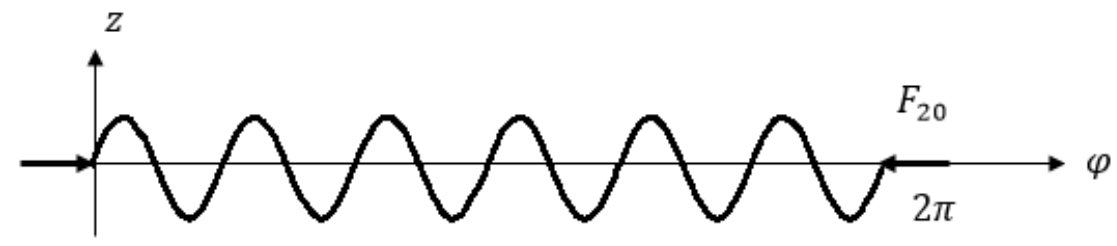

Рис. 3 - Плоский гофрований стрижень 3 параметрами гофри (1)

Розв'язок задачі (рис. 3) було отримано в [4] на основі асимптотичної гомогенізації:

$$
F_{20}=E S k^{-1} u_{20 \varphi}
$$

де $k=\frac{s}{\pi l} \int_{0}^{\pi} z^{2} A d \xi+\frac{1}{\pi} \int_{0}^{\pi} A^{-1} d \xi$.

Замінюючи в (12) поздовжню деформацію плоского стрижня $u_{20 \varphi}$ на окружну, неважко отримати нульове наближення шуканої залежності

$$
u_{10}=a k \frac{q R^{2}}{E F} .
$$


Задача проєктування. Однією з головних переваг асимптотичної гомогенізації для прогнозування напружено-деформованого стану гофрованих конструкцій $є$ можливість постановки та вирішення задач оптимального проєктування. Ці задачі пов'язані з вибором форми профілю, яка забезпечує необхідні механічні характеристики гофрованих конструкцій. У цьому розділі задачею $є$ вибір форми, яка дає найменше значення ефективних модулів пружності в (13), коли загальна довжина криволінійної осі фріксована

$$
\begin{gathered}
k \rightarrow \min _{z} ; \\
a=\text { const } ; \\
z(0)=z(\pi)=0 .
\end{gathered}
$$

Розв'язок варіаційної задачі (14) - (16) було отримано в [4] для поздовжньої деформації гофррованого стрижня (рис. 3):

$$
z= \pm \frac{\pi r}{\left(1-r^{2}\right) n h K(r)} \operatorname{sn}\left(2 K(r) \frac{n h \xi}{\pi}, r\right)
$$

Тут параметр $r$ визначає довжину дуги хвилі гофри.

На рис. 4 зображено оптимальний профріль (17) для $r=0,4 ; 0,6 ; 0,8$. Хрестами позначено відповідні синусоїдальні профілі однакової довжини дуги.

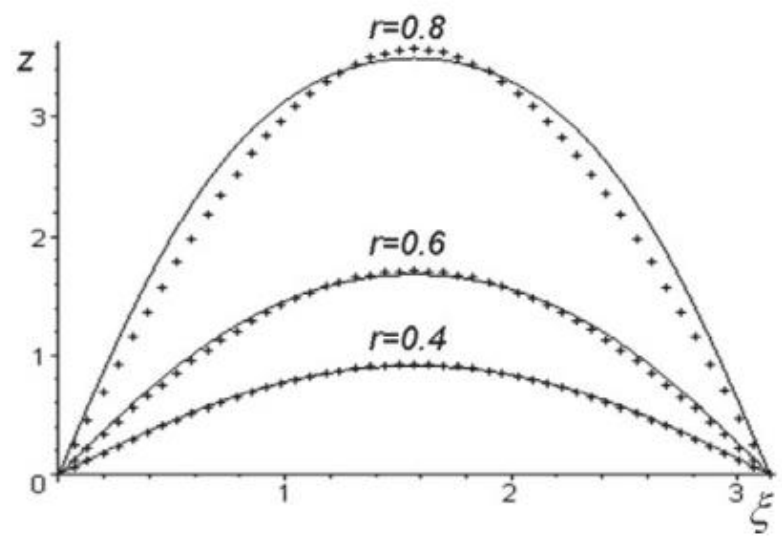

Рис. 4 - Оптимальний профіль гофри для $r=0,4 ; 0,6 ; 0,8$

Підставивши вираз (17) в (13), можна визначити значення $u_{1}$ для синусоїдального профрілю $u_{1 s}$ та для оптимального $u_{1 o}$. Відносно варіації $r$ маємо 


$$
\delta=\frac{u_{1 o}-u_{1 s}}{u_{1 s}} \cdot 100 \%
$$

3 (18) отримуємо, що для вибраних значень $r=0,4 ; 0,6 ; 0,8$ заміна синусоїдального профілю на оптимальний зменшує деформацію (13) на $\delta=0,065 ; 0,23 ; 0.365 \%$ відповідно.

Висновки. Застосування методу асимптотичної гомогенізації дозволило отримати асимптотичну фрормулу залежності величини деформації вертикально гофрованого кільця від величини зовнішнього тиску, що $є$ корисною попередньої інфрормацією при проєктуванні судинних стентів. Знайдений оптимальний профріль по ефективності виявився близьким до синусоїдального, зменшення деформації склало менше одного відсотка. Отримані геометричні характеристики вертикально гофрованого кільця можуть бути корисними для подальшого вивчення механічних характеристик судинних стентів, наприклад, в задачах стійкості.

\section{БІБЛІОГРАФІЧНІ ПОСИЛАННЯ}

1. Andrianov I.I., Andrianov, I.V., Diskovsky, A.A., Ryzhkov, E.V. Buckling of corrugated ring under uniform external pressure. Symmetry. 2020. Vol. 12(8). P.1250-1262.

2. Andrianov I.V., Awrejcewicz J., Diskovsky A.A.. Design optimization of FGM beam in stability problem. Engineering Computations. 2019. Vol. 36. Iss. 1. P. 248-270.

3. Andrianov I.V., Awrejcewicz J., Diskovsky A.A.. The Optimal Design of a Functionally Graded Corrugated Cylindrical Shell under Axisymmetric Loading // Int. Journal of Nonlinear Sciences and Numerical Simulation. 2019. Vol. 20(3-4). P. 387-398.

4. Syerko E., Diskovsky A.A., Andrianov I.V., Comas-Cardona S., Binetruy Ch. Corrugated beams mechanical behavior modeling by the homo-genization method // Int. J. Solids Struct. 2013. Vol. 50. P. 928-936.

\section{Удк 539.3}

А. А. Дисковский, д-р техн. наук, Ю. П. Синицына, канд. техн. наук, О. Д. Станина, канд. техн. наук

\section{ОПТИМАЛЬНОЕ ПРОЕКТИРОВАНИЕ ГОФРИРОВАННЫХ КОЛЕЦ КАК ЭЛЕМЕНТОВ СОСУДИСТЫХ СТЕНТОВ}

Рассмотрена деформация кольца, гофрированного перпендикулярно радиусу, находящегося под действием внешнего давления. Применён метод асимптотической гомогенизации. Получена асимптотическая формула зависимости величины деформации от величины внешнего давления для произвольного гладкого профиля гофры. Поставлена задача оптимизации формы профиля гофры по отношению к противодействию внешнему давлению. Найденный оптимальный профиль по своей эффективности оказался близким к синусоидальному, уменьшение деформации составило менее одного процента. 
Ключевые слова: сосудистый стент; гофрированное кольцо; внешнее давление; метод асимптотической гомогенизации; зависимость деформации от внешнего давления; оптимизация формы профиля гофры.

UDC 539.3
A. A. Diskovsky, Dr. Sci. (Tech.), Y. P. Synytsina, PhD (Tech.), O. D. Stanina, $P h D$ (Tech.)

\section{OPTIMAL DESIGN OF CORRUGATED RINGS AS ELEMENTS OF VASCULAR STENTS}

The deformation of a corrugated perpendicular to the radius ring under the action of external pressure is considered. The method of asymptotic homogenization is used. The asymptotic formula for the dependence of the deformation value on the external pressure value for an arbitrary smooth corrugation profile was obtained. The problem of optimization of the corrugated profile shape in relation to the resistance of external pressure was set. The found optimal profile in its effectiveness was close to sinusoidal; the reduction of deformation was less than one percent.

Keywords: vascular stent; corrugated ring; external pressure; method of asymptotic homogenization; dependence of deformation on external pressure; optimization of the corrugated profile shape.

Recently, corrugated rings (Fig. 1) used as components of vascular stents (Fig. 2). These structures are usually modeled using finite element analysis, but there is also a need for more simplified approaches to assessing possible design options. The aim of the work is to design a form of corrugation, which provides the greatest annular stiffness of the corrugated ring at a given perimeter. To do this, a homogeneous model of the corrugated ring is using the method of asymptotic homogenization [1 - 3].

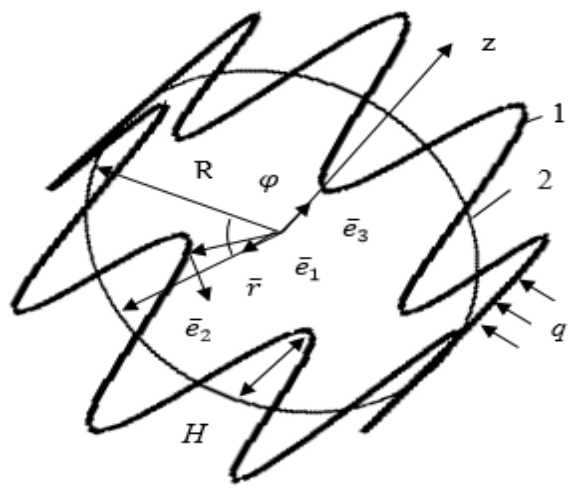

Fig. 1 - Corrugated ring:

$1 ; 2$ - base ring equidistant from the tops of the corrugations;

$H$-- amplitude of corrugations; q - normal to the cylindrical surface of radius $R$ distributed load acting from the walls of the vessel 


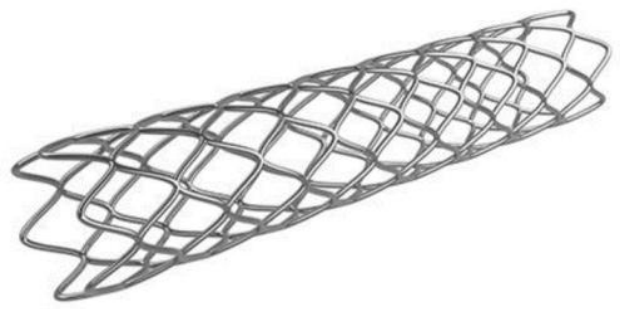

Fig. 2 - Example of a vascular stent [DAIS NEWS. June 12. 2017. Open Access]

Geometric relations. Vector equation of the centerline in a cylindrical coordinate system (Fig. 2)

$$
\bar{r}=\overline{R e}_{1}+Z(n \varphi) \bar{e}_{3},
$$

where $Z=H \theta(n \phi) ; \quad H$ is the amplitude of the corrugation; $\theta(n \varphi)$ is a periodic function with period $2 \pi / n ; n$ is the number of corrugated waves. The function $\theta(n \varphi)$, which determines the shape of the corrugation, is symmetric with respect to the base circle 2 (Fig. 2), $-1 \leq \theta(n \varphi) \leq 1,0 \leq \varphi \leq 2 \pi$.

Equilibrium equation. Consider a corrugated element of length ds and the forces acting on it, we obtain equation of equilibrium in projections on the axis of the base circle

$$
\begin{gathered}
F_{2 \phi \phi}-F_{2}=-R A q ; \\
M_{3 \phi \phi \phi}+M_{3 \phi}=R^{2} A_{\phi} q .
\end{gathered}
$$

Homogenization of equilibrium equations. Presented projections of internal forces and moment (2), (3) in the form

$$
F_{i}=\sum_{k=0}^{\infty} n^{-k} F_{i k}(\varphi, \xi) ; M_{i}=\sum_{k=0}^{\infty} n^{-k} M_{i k}(\varphi, \xi),
$$

where $\xi=n \varphi, F_{i k}, M_{i k}$ - periodic functions on $\xi$ with period $2 \pi$. Substituting the expansion (4) into equations (2), (3), after dividing by powers of $n$ and applying the averaging operator $\int_{0}^{2 \pi}(\ldots) d \xi$, we obtain

$$
F_{20}=R_{a q} ; F_{10}=0 ; M_{10}=M_{20}=M_{30}=0 .
$$


Deformation equation. To establish the dependence $u_{1}=u_{1}(q)$ consider the compression of a flat corrugated rod by forces $F_{20}$ and equate its deformation to the corrugated ring deformation $\varepsilon=\frac{u_{1}}{R}[4]$ :

$$
u_{10}=a k \frac{q R^{2}}{E F},
$$

where $k=\frac{s}{\pi} \int_{0}^{\pi} z^{2} A d \xi+\frac{1}{\pi} \int_{0}^{\pi} A^{-1} d \xi$.

Design problem. In this section, the problem is to choose the shape that gives the smallest value of the effective modulus of elasticity in (13), when the total length of the curvilinear axis is fixed

$$
\begin{gathered}
k \rightarrow \min _{z} ; \\
a=\text { const } ; \\
z(0)=z(\pi)=0 .
\end{gathered}
$$

The solution of the variational problem (7) - (9) was obtained in [4] for the longitudinal deformation of the corrugated rod

$$
z= \pm \frac{\pi r}{\left(1-r^{2}\right) n h K(r)} \operatorname{sn}\left(2 K(r) \frac{n h \xi}{\pi}, r\right) .
$$

The parameter $r$ determines the arc wavelength of the corrugation.

If we compare deformation for the sinusoidal profile $u_{1 s}$ and for the optimal $u_{1 o}$ :

$$
\delta=\frac{u_{1 o}-u_{1 s}}{u_{1 s}} \cdot 100 \%
$$

We obtain that for the selected values of $r=0,4 ; 0,6 ; 0,8$ replacement of the sinusoidal profile by the optimal one reduces the deformation by $\delta=0,065 ; 0,23 ; 0,365 \%$, respectively.

Conclusions. The application of the method of asymptotic homogenization allowed obtaining an asymptotic formula for the dependence of the amount of deformation of the vertically corrugated ring on the value of external pressure, which is useful preliminary information in the design of vascular stents. The found optimal efficiency profile was close to sinusoidal; the 
reduction of deformation was less than one percent. The obtained geometrical characteristics of the vertically corrugated ring can be useful for further study of the mechanical characteristics of vascular stents, for example in stability problems.

\section{REFERENCES}

1. Andrianov I.I., Andrianov, I.V., Diskovsky, A.A., Ryzhkov, E.V. Buckling of corrugated ring under uniform external pressure. Symmetry. 2020. Vol. 12(8). P.1250-1262.

2. Andrianov I.V., Awrejcewicz J., Diskovsky A.A.. Design optimization of FGM beam in stability problem. Engineering Computations. 2019. Vol. 36. Iss. 1. P. 248-270.

3. Andrianov I.V., Awrejcewicz J., Diskovsky A.A.. The Optimal Design of a Functionally Graded Corrugated Cylindrical Shell under Axisymmetric Loading // Int. Journal of Nonlinear Sciences and Numerical Simulation. 2019. Vol. 20(3-4). P. 387-398.

4. Syerko E., Diskovsky A.A., Andrianov I.V., Comas-Cardona S., Binetruy Ch. Corrugated beams mechanical behavior modeling by the homo-genization method // Int. J. Solids Struct. 2013. Vol. 50. P. 928-936.

Дніпропетровський державний університет внутрішніх справ, Дніпро, Україна

Надійшла до редколегії 02.09.2021 